\title{
Is Cerebral Arteritis the Cause of the Landau-Kleffner Syndrome? Four Cases in Childhood with Angiographic Study
}

\author{
Ignacio Pascual-Castroviejo, V. López Martín, A. Martínez Bermejo and A. Pérez Higueras
}

\begin{abstract}
Four children with Landau-Kleffner syndrome were studied over a six year period. They presented with acquired aphasia, epilepsy, and focal or generalized EEG discharges which were exacerbated during sleep. In addition, cerebral angiography demonstrated isolated arteritis of some branches of the carotid arteries in all cases. Computed tomographic and magnetic resonance images were normal. Nicardipine in a dose of 1 to $2 \mathrm{mg} / \mathrm{kg} / \mathrm{day}$, added to conventional anticonvulsant drugs provided effective supplementary control of seizures, of paroxysmal EEG discharges, and of language and behavioural disturbances, even several years after the onset of the disorder and in patients whose response to other medications, including steroids, had been poor. Interruption of nicardipine administration was followed by relapse of the language disorder. Repeat angiography was performed in all four patients and showed recanalization of obstructed vessels in two cases. Focal cerebral vasculitis may be the pathogenesis of the Landau-Kleffner syndrome and calcium channel blockers such as nicardipine may be effective and specific therapy.
\end{abstract}

RÉSUMÉ: L'artérite cérébrale est-elle la cause du syndrome de Landau-Kleffner? Une étude longitudinale de quatre cas d'aphasie acquise et d'épilepsie dans l'enfance avec étude angiographique. Nous avons procédé à une étude longitudinale sur une période de six ans chez quatre enfants porteurs du syndrome de Landau-Kleffner. Ils se sont présentés avec une aphasie acquise, une épilepsie et des décharges focales ou généralisées à 1'EEG, exacerbées pendant le sommeil. De plus, l'angiographie cérébrale a montré une artérite isolée de certaines branches des artères carotides dans tous les cas. L'imagerie par tomodensitométrie et par résonance magnétique étaient normales. La nicardipine à dose de 1 ou $2 \mathrm{mg} / \mathrm{kg}$ /jour ajoutée aux médications anticonvulsivantes conventionnelles a amené un contrôle supplémentaire des crises, des décharges EEG paroxistiques et des perturbations du langage et du comportement, même plusieurs années après le début de la maladie et chez des patients dont la réponse thérapeutique à d'autres médications, incluant les stéroïdes, avait été médiocre. L'interruption de l'administration de la nicardipine a été suivie d'une récidive du problème du langage. Une angiographie de contrôle a étể effectuée chez les quatre patients et a montré une recanalisation des vaisseaux obstrués dans deux cas. La vasculite cérébrale focale est peut être la pathogenèse du syndrome de Landau-Kleffner et les inhibiteurs des canaux calciques tels la nicardipine peuvent être un traitement efficace et spécifique.

Can. J. Neurol. Sci. 1992; 19:46-52

In 1957, Landau and Kleffner described six children with a syndrome of acquired aphasia associated with seizures. ${ }^{1}$ It usually occurs in normal children who lose receptive and expressive language ability, mostly gradually, though at times with a rapid onset and coincidental with generalized spike-wave complexes in the electroencephalogram (EEG). Receptive aphasia and behavioral disturbances dominate the clinical presentation and the affected children are often thought to be autistic or deaf. Seizures may precede or follow the onset of the language disturbances although they are not universally present. Electroencephalographic discharges are, however, always present.
About 200 patients have now been described with different eponyms in several languages. ${ }^{1-27}$ Acquired receptive aphasia is considered essential to the diagnosis of Landau-Kleffner syndrome. Epilepsy, however, becomes manifest in only $70 \%$ of cases, ${ }^{22}$ although the presence of paroxysmal EEG abnormalities is another diagnostic criterion with or without clinical seizures. ${ }^{19,23}$ The etiology of the disorder is controversial. Several possible causes have been suggested ${ }^{4,5,18,24,27}$ but most authors regard the syndrome to be of unknown origin.

During the past six years, we have studied four patients with acquired aphasia and epilepsy. Arteriography of both carotids was performed in every case and images suggestive of arteritis

From the Departments of Paediatric Neurology and Neuroradiology, Hospital Infantil "La Paz", Madrid, Spain

Received June 19, 1990. Accepted in final form August 12, 1991

Reprint requests to: Dr. I Pascual-Castroviejo, Servicio de Neurología Infantil, Hospital "La Paz", Paseo de la Castellana 261, Madrid 28046, Spain 
were observed in all four. All patients showed major improvement in the clinical and EEG disturbances after a calcium channel blocker was added to the conventional antiepileptic drugs that had previously shown low efficacy. ${ }^{28}$

\section{Material and Methods}

Patient 1 A now 15-year-old right-handed boy had been the product of an uncomplicated gestation and delivery. He walked at 9 months, spoke his first words at 12 months, and put words together by 16-17 months. At age 7 years, he gradually developed difficulty in speaking some words and had a diminished comprehension of verbal commands, becoming aphasic after two months. An EEG showed many spike-wave discharges over both hemispheres, although they were most prominent in the left temporal lobe. Routine blood and cerebrospinal fluid (CSF) studies were normal. At $7^{1 / 2}$ years, he developed generalized seizures of short duration. Computed axial tomography (CT) of the brain was normal. Carotid arteriography showed images consistent with arteritis, especially located in the posterior branches of the left middle cerebral artery. Laboratory studies for viral and systemic collagen vascular diseases were normal.

The child was treated with prednisone $(30 \mathrm{mg} / \mathrm{day})$ for two weeks, then the dose was tapered at a rate of $5 \mathrm{mg}$ every two weeks. He also received carbamazepine $(14 \mathrm{mg} / \mathrm{kg} / \mathrm{day})$. The language disorder persisted unchanged over three years and the patient had two partial seizures. At 10 years of age the boy was not able to understand or to speak. The EEG showed paroxysmal discharges over both hemispheres (Figure 1). Auditory evoked potentials were normal. At this time, the patient was given a daily dose of $60 \mathrm{mg}$ of nicardipine, as a supplement to his antiepileptic medication (carbamazepine). After six months he was able to understand many things, though he still did not speak.

Between 10 and 15 years of age, the patient remained free of clinical seizures. Language function recovered slowly, so that at 15 years he now speaks many words in a comprehensible context and is able to read, write, add, subtract, multiply and divide; although at a basic level. His EEG in an awake state has shown normal results every year. However, at 15 years an EEG performed during sleep revealed focal paroxysmal discharges over the left frontotemporal region with homologous contralateral spread. Angiography also was repeated at this age, showing the same appearance of arteritis observed in the initial study. Magnetic resonance imaging (MRI) was interpreted as normal.

Patient 2 This 15-year-old right-handed male was the product of an uncomplicated pregnancy and delivery. Development milestones were normal: he walked and used his first words at 13 months. The boy had normal psychomotor and language development (he had learned only the Catalonian language) until $6^{1 / 2}$ years of age when he experienced a generalized seizure. Within several months the patient developed a progressive language disorder and six months later he showed almost total unresponsiveness to oral communication. The EEG revealed generalized paroxysmal abnormalities. Treatment was instituted with 30 $\mathrm{mg} / \mathrm{kg} /$ day of valproic acid (VPA), $3 \mathrm{mg} /$ day of clonazepam (CZP) and speech therapy. He remained free of seizures for three years while taking VPA alone, and learned to speak and write in Spanish but he forgot the Catalonian language used before the onset of his illness. At 10 years of age he presented with fever of $38^{\circ} \mathrm{C}$, associated with a rash on the face, knees, ears, genital organs and creases of the body. Within a week the boy had totally lost speech comprehension and expression as well as sphincter control, and showed anxious behaviour. He was still able to eat, dress, wash and ride a bicycle, however. The EEG showed multifocal discharges over both cerebral hemispheres and the patient was diagnosed as having acquired aphasia with epilepsy. Carbamazepine ( 3 $\mathrm{mg} / \mathrm{kg} /$ day) was added to the $30 \mathrm{mg} / \mathrm{kg} / \mathrm{day}$ of VPA, but neither the language nor the EEG improved and he failed to recognize objects or people.

At 11 years of age examination revealed verbal auditory agnosia with mutism and autistic behaviour without any response or reaction to stimuli. He presented a tendency to a genuflexed posture, open mouth with drooling, and osteotendinous hyperreflexia.

CSF showed a moderate elevation of protein $(0.60 \mathrm{~g} / \mathrm{l})$ as the only alteration. An EEG disclosed an active epileptogenic focus in the right parietotemporal region with contralateral transmission (Figure 2A). CT and MRI studies were normal. Bilateral carotid arteriography was per- formed and showed images suggestive of disseminated arteritis in both hemispheres, but predominantly on the right. Laboratory studies for infectious and systemic metabolic diseases were normal.

Nicardipine in a dose of $40 \mathrm{mg} /$ day divided in two doses, was added to the previous anticonvulsant therapy which was maintained at the same dose. Language functions recovered slowly but progressively and six months later he was able to speak and carry on uncomplicated conversations. He still experienced some difficulty in understanding. During this half year he recovered sphincter control and a normal gait. The EEG abnormalities had disappeared and the CSF showed $0.48 \mathrm{~g} / \mathrm{l}$ of proteins. The dose of nicardipine was increased to $60 \mathrm{mg} /$ day. At 12 years of age CSF proteins were $0.36 \mathrm{~g} / \mathrm{l}$; he was able to add and subtract normally and to multiply and divide by one number; his EEG was normal; psychological testing (WISC) showed a performance IQ of 62 , but he did not achieve the minimal score in the verbal IQ.

Improvement continued slowly over the following years. At the age of 14 years, arteriography was repeated and now showed recanalization of narrowed arteries without collateral vessels. At 15 years, he is able to understand, speak and write both Spanish and Catalonian (his first language), he can manage money, ride a bicycle and dress himself. His behaviour is hyperactive and talkative. The EEG repeatedly had been normal, but at 15 years it showed mild focal abnormalities in the left temporal lobe (Figure 2B). Another CSF study showed increased proteins $(0.70 \mathrm{~g} / \mathrm{l})$ with normal glucose and cells. Seizures did not appear

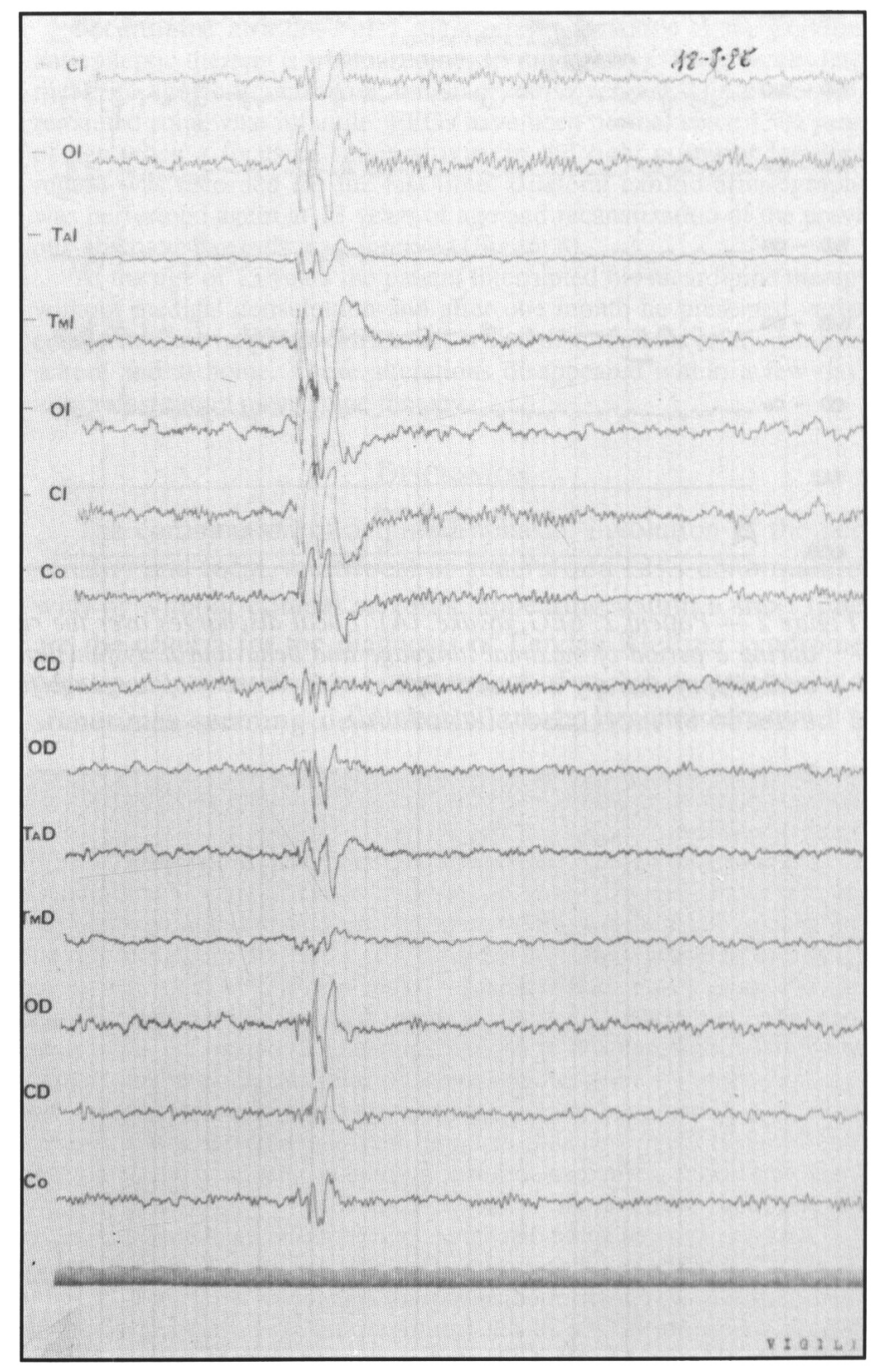

Figure I-Patient 1.EEG, awake. Brief generalized paroxysmal discharges while receiving antiepileptic treatment. 

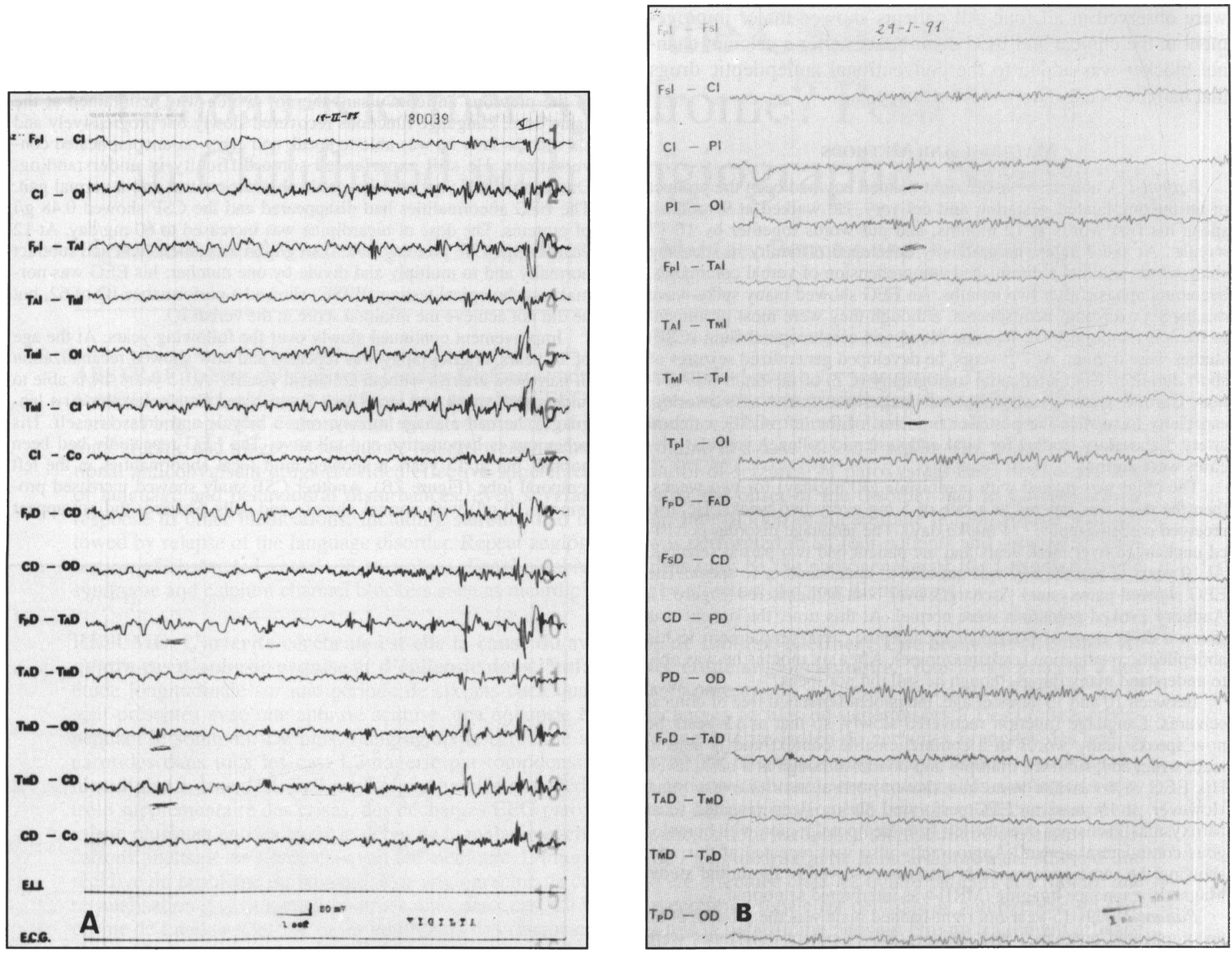

Figure 2 - Patient 2. EEG, awake. (A): Focal discharges over the right frontocentrotemporal regions (underlined) with secondary generalization during a period of maximal language and behavioural dysfunction while receiving antiepileptic therapy. (B): Four years later, while receiving antiepileptic therapy and nicardipine, with recovery of language function and without seizures; mild focal discharges appear over the left centroparietotemporal regions (underlined).

and he continues to improve his language (Catalonian and Spanish) and mental functions.

Patient 3 A 12-year-old left-handed girl was referred because of mental retardation. She was the product of a full-term uncomplicated pregnancy and delivery. The patient had normal psychomotor and language development during the first $3 \frac{1}{2}$ years of life, although she always spoke using short sentences. At the age of $3 \frac{1}{2}$ years, her speech began to deteriorate; she asked for things by hand signals, but preserved a normal comprehension of spoken language. Between $3 \frac{1}{2} 2$ and 7 years her speech deteriorated progressively to mutism and intellectual function also diminished. She never had seizures. At age 7 years, her neurological exam revealed discrete muscular hypotonia with normal osteotendinous reflexes, combined aphasia and autistic behaviour. Ocular fundi were normal.

An EEG showed spike discharges over both hemispheres (Figure 3). Brain CT and MRI studies disclosed no abnormalities. Arteriography of both carotids was performed, revealing images of arteritis bilaterally, which was more severe in the frontoparietal zone, especially on the right side (Figure 4A, B). CSF studies showed normal protein content $(0.37 \mathrm{~g} / \mathrm{l})$. Extensive studies were performed for infectious, metabolic, immunological or blood coagulation disease, all of which were normal. She was treated with prednisone $(1 \mathrm{mg} / \mathrm{kg} / \mathrm{day})$ over one month, decreasing the dose at a rate of $5 \mathrm{mg}$ per week, phenytoin (4 $\mathrm{mg} / \mathrm{kg} / \mathrm{day})$, and nicardipine ( $1 \mathrm{mg} / \mathrm{kg} / \mathrm{day})$. After two months the girl began to communicate with her family by gesture although without understanding verbal speech. The epileptiform activity had disappeared from her EEG (Figure 5).

Between 1987 and 1991, the patient was reviewed every six months. All psychomotor parameters showed slow improvement. The EEG showed transient focal discharges in the right frontoparietal region with normal background rhythms, but brief bilateral discharges also were occasionally recorded. At 9 years of age, angiographic study of both carotid arteries was repeated, with results similar to those seen in the first study. At 11 years the CSF contained elevated proteins $(0.78 \mathrm{~g} / \mathrm{l})$ with normal cells and glucose. At 12 years the language disorder persists though she is able to speak single words and use short phrases.

Patient 4 A 17-year-old right-handed male patient was the product of a normal gestation and delivery. He remained well and achieved developmental milestones at appropriate ages: sitting alone by 6 months, walking by 11 months, using single words at 9 months, putting words together by 15 months, and learning to read and to write before 6 years.

At the age of 6 , he suffered his first convulsion, which began with rhythmical jerking of the right side of the body that became secondarily 
generalized. After the seizure the patient had a transient right hemiparesis for several hours. He was treated with $15 \mathrm{mg} / \mathrm{kg} /$ day of carbamazepine on a long-term basis. After several months the boy forgot how to read and write. Between the ages of 6 and 10, he did not experi-

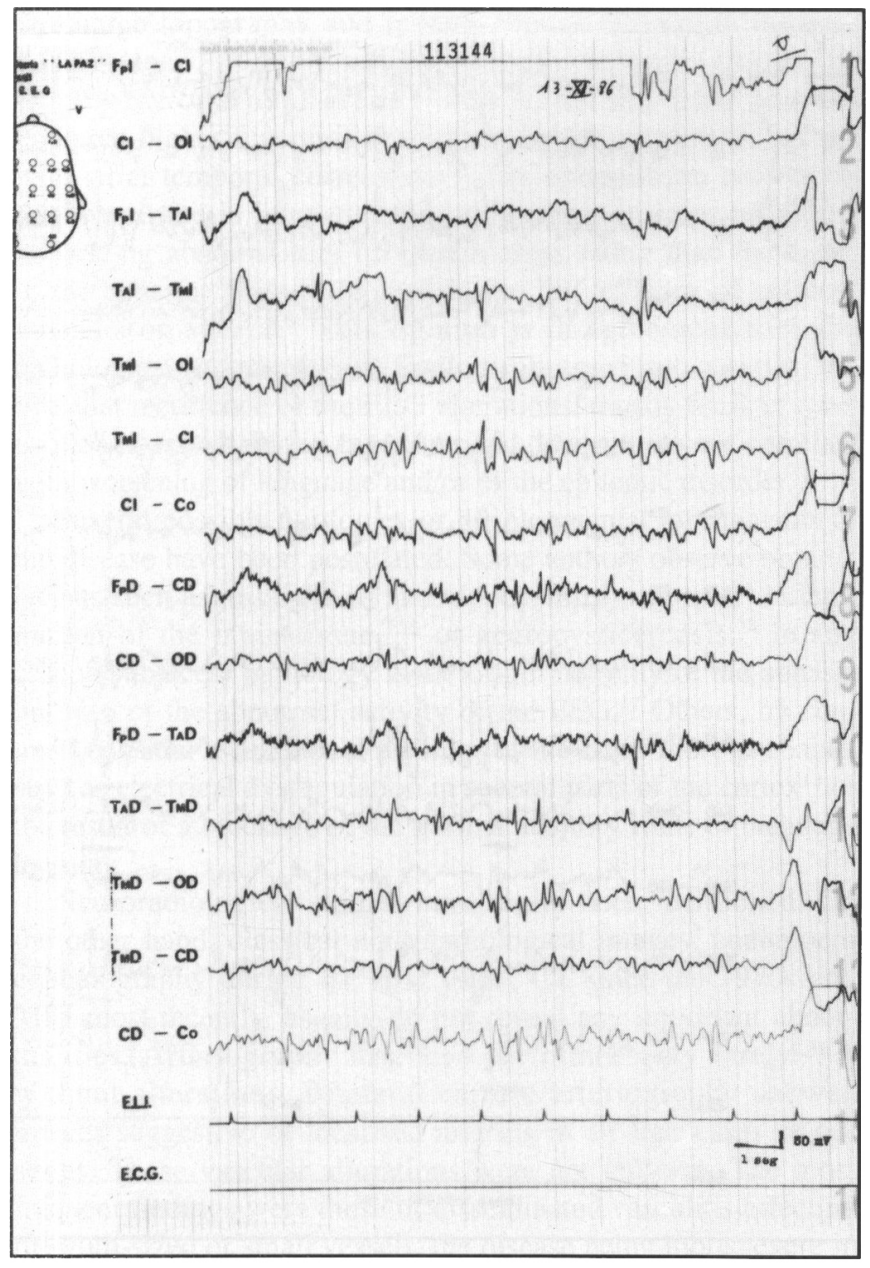

Figure 3-Patient 3. EEG awake, obtained prior to taking nicardipine. Spike discharges over both hemispheres.

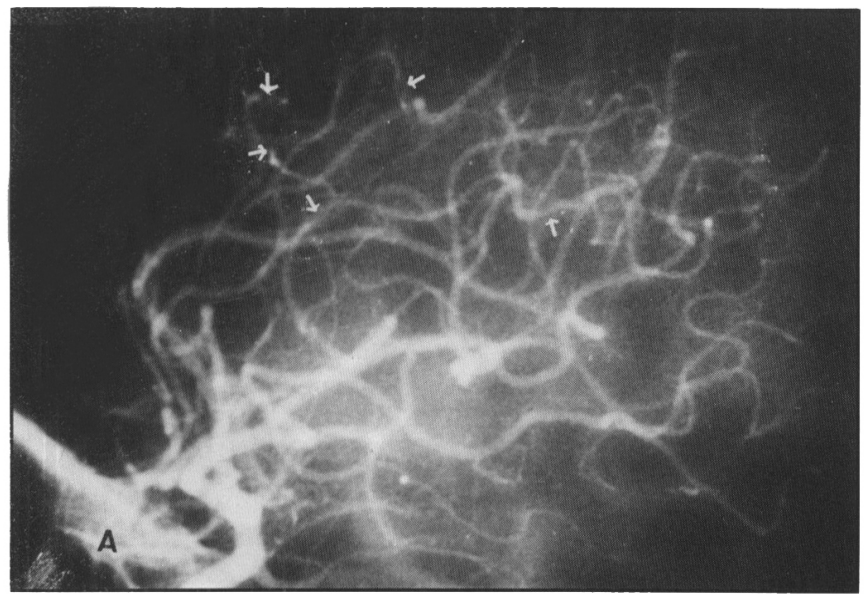

ence any further seizures, but his language deficits increased and he became completely unable to speak or understand any words.

At 10 years of age, he was mute and lacked contact with his environment. The EEG showed bilateral paroxysmal discharges, more severe over the right hemisphere. Audiometry and auditory evoked potentials revealed normal results. CT imaging of the brain was normal. Bilateral carotid arteriography showed images interpreted as arteritis involving middle sized and small vessels, with the most severe alterations in branches of the right middle cerebral artery (Figure 6). Investigation for metabolic, viral and immunological disease yielded normal results.

Prednisone in a dose of $1 \mathrm{mg} / \mathrm{kg} /$ day over four weeks was decreased at a rate of $5 \mathrm{mg} /$ week, added to the previous antiepileptic medication. One month later, the patient initiated contact with his surroundings and his EEG reverted to normal. After two months, he had recovered the use of language. Psychological testing (WISC) showed a verbal IQ of 61 ; performance IQ of 56; and combined IQ of 55 .

At 11 years of age, he began to leave out important words in sentences; he would leave sentences unfinished and began to develop word finding problems. His EEG at that time disclosed focal discharges in the right hemisphere. Treatment with prednisone was started and maintained over three months. He showed moderate improvement of language, but the focal EEG alterations persisted. At $11 \frac{1}{2}$ years of age, the patient suffered a focal seizure and responded with difficulty to oral commands. His language was very slow. An EEG showed generalized paroxysmal discharges and right temporal focal spikes (Figure 7).

Nicardipine in a dose of $1 \mathrm{mg} / \mathrm{kg} /$ day was added to the previous antiepileptic therapy (carbamazepine, $15 \mathrm{mg} / \mathrm{kg} /$ day). Three weeks later the EEG showed continuous language improvement. His personality remained somewhat infantile. EEGs have been normal since $13^{1 / 2}$ years of age when a focus of spike activity in the right posterior temporal region was recorded for the last time. Bilateral carotid arteriography was performed again at 13 years of age and recanalization of the previous obstructed vessels was observed (Figure 8).

At the age of 15 years the patient interrupted his nicardipine therapy without medical consultation and after one month he presented verbal comprehensive language difficulties which disturbed his relationships at school and at home. These alterations disappeared within a few days after reinstituting nicardipine therapy.

\section{Discussion}

The combination of acquired aphasia, involution of the personality and focal, multifocal or generalized EEG abnormalities with or without clinical seizures, appearing within a short time, are the criteria for the diagnosis of Landau-Kleffner syndrome. Most patients have severe impairment of verbal comprehension, sometimes seeming deaf. Autistic behaviour is observed in

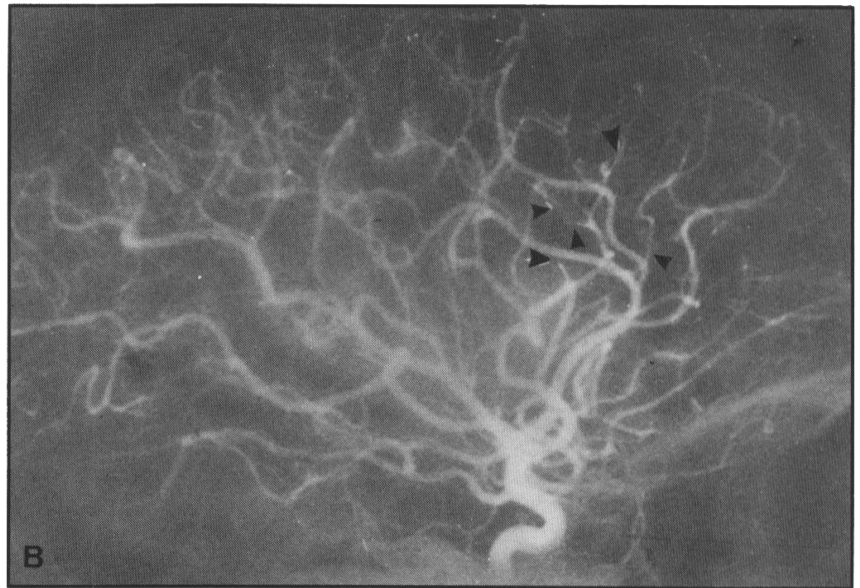

Figure 4-Patient 3. (A): Left lateral carotid angiogram shows narrowing and occlusion of vessels of middle size (arrows) of unknown origin. (B): Right lateral carotid angiogram of the same case reveals narrowing, occlusion and ectasia in branches of the middle cerebral artery, especially in the territory of the opercular artery (arrows). 
many patients, at least during some phases of the disease. Hyperactivity has been reported as one of the most frequent behavioural abnormalities, ${ }^{3-5,14,17}$ although in our series hyperki-

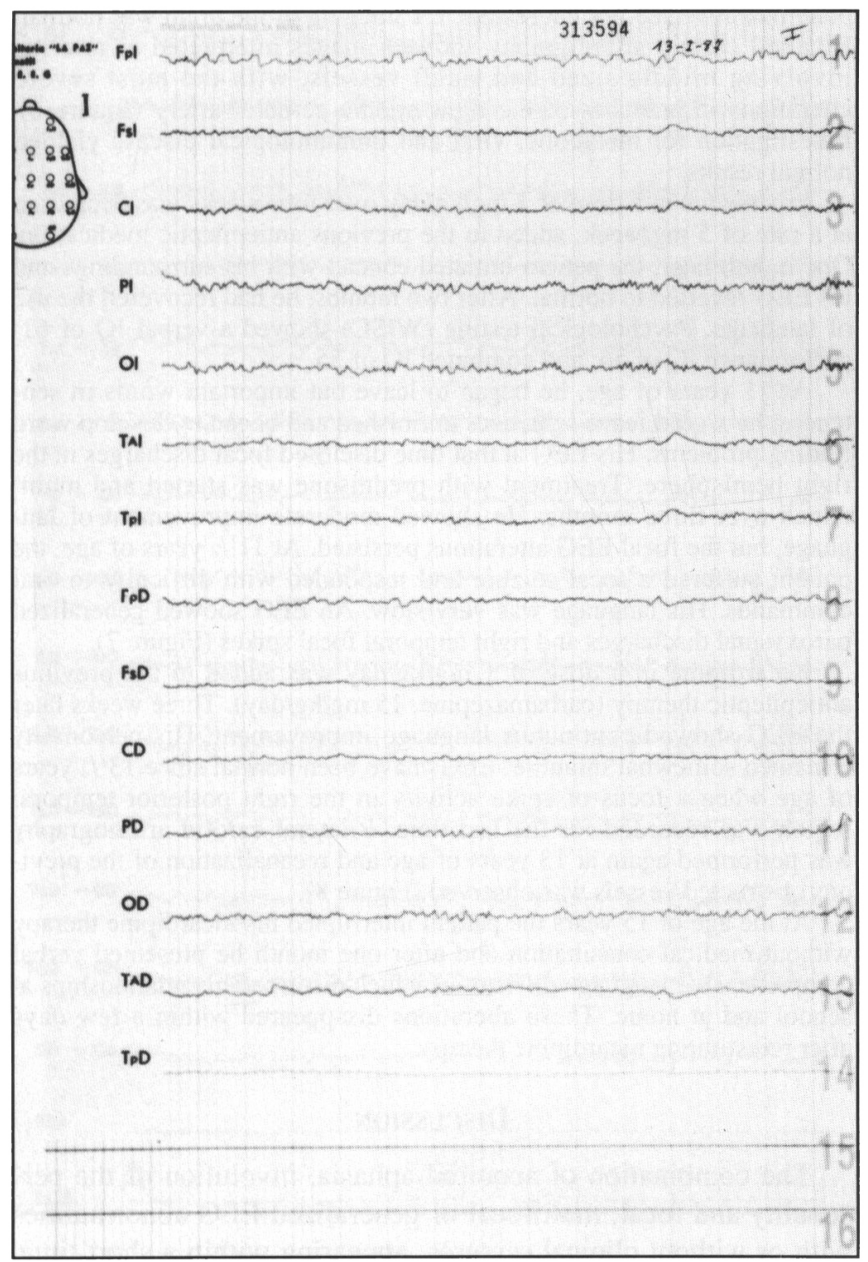

Figure 5-Patient 3. Normal EEG, awake, recorded two months after the EEG shown in Figure 3 and while receiving nicardipine.

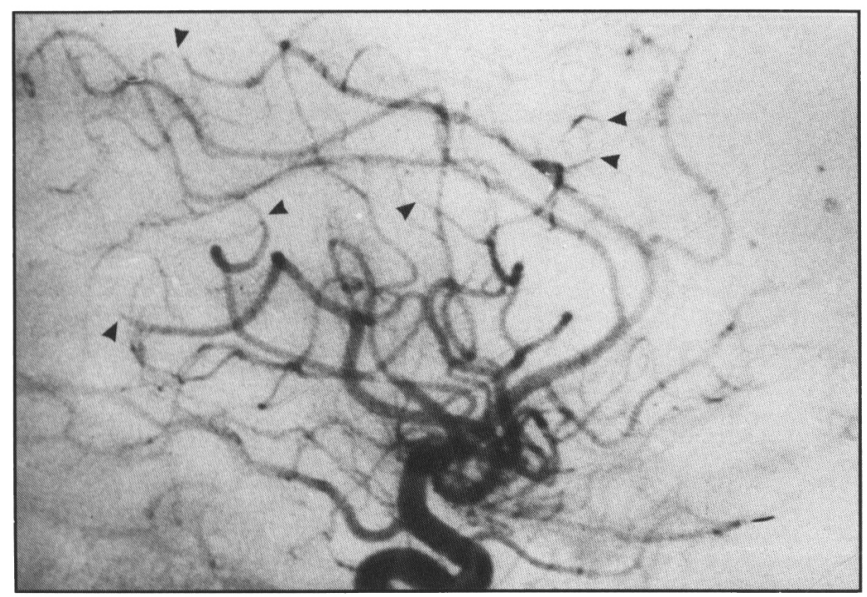

Figure 6-Patient 4. The right lateral carotid angiogram at 10 years of age reveals occlusion and narrowing of vessels of middle size (arrows) of unknown origin. nesia appeared most commonly during recovery after treatment. This syndrome usually has an onset between 18 months and 10 years. ${ }^{15}$
Figure 7-Patient 4. EEG, awake, at 12 years of age, prior to taking nicardipine. Paroxysmal right focal discharges with contralateral spread are seen.

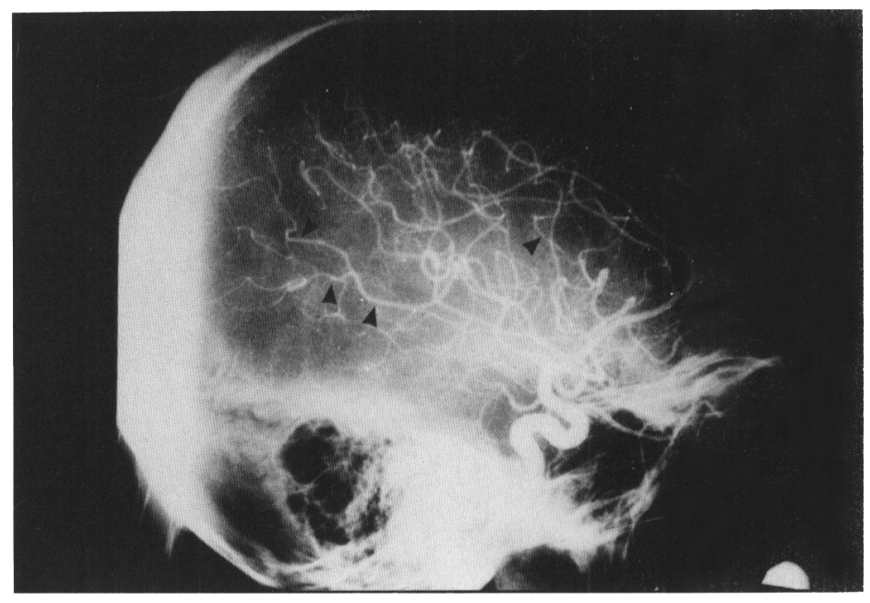

Figure 8-Patient 4. Right lateral carotid angiogram at 13 years of age, after one year of nicardipine therapy. The obstructed arteries seen in Figure 6 have recanalized (arrows). 
The EEG abnormalities are variable. The most common alteration consists of generalized spike-wave discharges, although these discharges may be multifocal with shifting predominance, but mainly temporal in $85 \%$ of reported cases, and are unilateral and also predominantly temporal in $15 \% .^{2}$ Discharge topography and pattern change frequently increase during sleep, $, 5,16,19,26$ having a higher expressivity in the frontocentroparietal areas. ${ }^{11}$ The abnormal EEG and the impaired higher functions develop and regress together, but not with strict temporal correlation. ${ }^{22}$ The epileptiform activity in this syndrome is interpreted as an epiphenomenon reflecting underlying abnormalities of speech areas rather than the cause of the aphasia. This could explain the low efficacy of anticonvulsants on speech. ${ }^{8}$ This opinion is in agreement with the pathological and therapeutic findings observed in our series. We find that recurrence of the EEG alterations, mostly focal in type, is often observed during treatment and does not always correlate with worsening of language and/or of the epileptic disorder.

Several possible etiologies or developmental mechanisms of the disease have been postulated. Some authors observe organic lesions such as mild gliosis and hippocampal sclerosis, ${ }^{2}$ inflammation of the brain tissue,,$^{7,12}$ or neurocysticercosis; ${ }^{24}$ in any case, a subjacent pathology is the origin not only of the aphasia but also of the abnormal activity of the EEG. ${ }^{17}$ Others, by contrast, consider a functional disorder of the brain more probable, such as electrical dysregulation in several parts of the cortex ${ }^{12}$ or the result of a blockage of the normal auditory route to language learning. ${ }^{7}$

Neuroradiological studies have rarely been mentioned. On the other hand, classical neuroradiological images, pneumoencephalography during the first years, CT since the 1970 s and MRI most recently, usually do not reveal any important abnormalities. Arteriography has been performed only rarely ${ }^{2,16,20}$ without alterations. Bilateral carotid arteriography showed images suggestive of localized arteritis in all four cases of our series. These vascular alterations were not uniform. The most frequent findings were those of disseminated vasculitis affecting medium-sized or small vessels, the disease being more severe in one hemisphere. Opercular arteries were the most frequently and severely affected.

Arteriographic irregularities and/or obstructions may change after treatment with calcium channel blockers and recanalization of previously obstructed arteries, as seen in two of our four patients in whom serial arteriography was performed. It is very difficult to include the patients in our series in any pathogenic classification of cerebral arteritis. ${ }^{29}$ These patients seem to present isolated angiitis of the CNS. ${ }^{30,31}$ This disorder is an uncommon clinicopathological entity characterized by vasculitis restricted to some cerebral vessels without apparent systemic vasculitis. Angiography can be valuable and indeed diagnostic if characteristic irregular narrowings of the small and mediumsized cerebral vessels are seen..$^{30}$

Mild to moderate elevation of CSF proteins is usually found in isolated angiitis of the brain, ${ }^{30,31}$ and in some previously reported cases of Landau-Kleffner syndrome. ${ }^{3,18}$ Elevation of CSF protein was also seen in two of the three patients of our series whose CSF was studied; and may be the expression of a low grade focal inflammation of the brain.

The etiology of the arteritis remains unknown in our cases, even after laboratory studies to investigate infectious, immuno- logical and other systemic diseases. Inflammatory disorders may undergo relapses or remissions, especially when they are chronic, affecting brain and/or meninges including blood vessels. The fluctuating course of the aphasia, the EEG activity and CSF proteins, with periods of exacerbations and remissions $3,4,9,10,14,17$ could be related to the changing organic condition of the brain and perhaps influenced by the permeability of the affected arteries at that time.

Treatment of Landau-Kleffner syndrome is controversial. The efficacy of antiepileptic drugs on the seizures, the EEG alterations and the long term neuropsychological difficulties has been widely discussed. ${ }^{15,26,32,33}$ Corticosteroids have been used with a consistently beneficial effect on clinical, electroencephalographic and disturbed higher functions in some patients with Landau-Kleffner syndrome. ${ }^{13,16,18,26,32,34}$ The delay in response to steroids and the severity of the neuropsychological sequelae, however, seem to depend on the duration and the importance of clinical symptoms before starting treatment. ${ }^{32,34}$ In our experience, etiology of a possible cerebral arteritis would be another consideration. The response of EEG and neuropsychological alterations to corticoids was prolonged for a limited time.

Nicardipine, the only calcium antagonist used by us, has been safe and effective over several years without decreasing its positive effects over a prolonged period. Other calcium channel blockers have been demonstrated to possess anticonvulsant activity in some experimental seizure models ${ }^{35,36}$ as well as in clinical seizures in humans. ${ }^{37}$ Clinical studies of calcium channel blockers in epilepsy have mainly focussed on the use of flunarizine as an adjuvant or supplementary drug in the treatment of seizures not controlled by conventional antiepileptic therapy. ${ }^{38,39}$ The anticonvulsant action of nicardipine, the first calcium antagonist derived from the dihydropyridines, has been previously described in epileptic patients who presented cerebral vascular disease. ${ }^{40}$ In our studies, only seizures appearing in patients with vascular disturbances showed a high response to nicardipine, always in association with other conventional antiepileptic drugs which previously had been ineffective. ${ }^{40}$ The therapeutic action of the calcium channel blockers in epilepsy has received little attention despite their potential for facilitating or enhancing the antiepileptic function of conventional drugs. This may be especially important in seizures induced by ischaemia, as has been observed in experimental animal models. ${ }^{35}$ Abnormal cerebral glucose utilization during sleep with lower metabolic rates in subcortical structures than in cortex have recently been described in patients with LandauKleffner syndrome by using positron emission tomography (PET). ${ }^{41}$

The evolution of this disease has been widely discussed. A prolonged follow-up period is necessary to obtain objective data on the long-term evolution of this syndrome. ${ }^{3,7.10}$ According to our observations, the most important variables predicting outcome are the severity, perhaps the etiology of the arteritis, its uni- or bilaterality more than its intracerebral location, and the early initiation of treatment including perhaps the use of calcium channel blockers for long continuous periods as supplementary therapy to antiepileptic drugs. It is possible that corticosteroid therapy in high doses and with very early initiation may improve the prognosis. ${ }^{32}$ Bitemporal lesions or dysfunctions, however, imply a late, slow and possibly more incomplete 
recovery of the language disorder. ${ }^{5,15,41}$ Although in some series, a good prognosis has been emphasized, ${ }^{21}$ most publications are less optimistic and incomplete recovery is usually reported. ${ }^{2,5,7,10,12-15}$ The correlation between the seizures and/or the EEG abnormalities and the language disturbance remains an open question.

\section{ACKNOWLEDGEMENTS}

We are grateful to Dr. Harvey B. Sarnat, Head of the Service of Pediatric Neurology of the Alberta Children's Hospital in Calgary (Canada), for his invaluable help to write this paper in a more understandable English.

\section{REFERENCES}

1. Landau WM, Kleffner FR. Syndrome of acquired aphasia with convulsive disorder in children. Neurology 1957; 7: 523-530.

2. Cole AJ, Andermann F, Taylor L, et al. The Landau-Kleffner syndrome of acquired epileptic aphasia: unusual clinical outcome, surgical experience, and absence of encephalitis. Neurology 1988; 38: 31-38

3. Mantovani JF, Landau WM. Acquired aphasia with convulsive disorder: course and prognosis. Neurology 1980; 30: 524-529.

4. Lou HC, Brandt S, Bruhn P. Aphasia and epilepsy in childhood. Acta Neurol Scand 1977; 56: 46-54.

5. Gascon G, Victor D, Lombroso CT, et al. Language disorder, convulsive disorder and electro-encephalographic abnormalities. Arch Neurol 1973; 28: 156-162.

6. Worster-Drought C. An unusual form of acquired aphasia. Dev Med Child Neurol 1971; 13:563-571.

7. Bishop DVM. Age of onset and outcome in "acquired aphasia with convulsive disorders" (Landau-Kleffner syndrome). Dev Med Child Neurol 1985; 27: 705-712.

8. Holmes GL, McKeever M, Saunders Z. Epileptiform activity in aphasia of childhood: an epiphenomenon? Epilepsia 1981; 22: 631-639.

9. Deonna T, Beaumanoir A, Gaillard, F, et al. Acquired aphasia in childhood with seizures disorder: a heterogenous syndrome. Neuropädiatrie 1977; 8: 263-273.

10. Deonna T, Peter C, Ziegler AL. Adult follow-up of the acquired aphasia-epilepsia syndrome in childhood. Report of 7 cases. Neuropediatrics 1989; 20: 132-138.

11. Nakano S, Okuno T, Mikawa H. Landau-Kleffner syndrome. EEG topographic studies. Brain Dev 1989; 11:43-50.

12. Ansink BJJ, Sarphatie H, van Dongen HR. The Landau-Kleffner syndrome. Case report and theoretical considerations. Neuropediatrics 1989; 20: 170-172.

13. Kellerman K. Recurrent aphasia with subclinical bioelectric status epilepticus. Eur J Pediatr 1978; 128: 207-212

14. Rapin I, Mattis S, Rowan AJ, et al. Verbal auditory agnosia in children. Dev Med Child Neurol 1977; 19: 192-207.

15. Dulac O, Billard C, Arthuis M. Aspects électrocliniques et évolutifs de l'épilepsie dans le syndrome aphasie-épilepsie. Arch Fr Pediatr 1983; 40: 299-308.

16. Dugas M, Masson M, Le Heuzey MF, et al. Aphasie "acquise" de l'enfant avec épilepsie (syndrome de Landau et Kleffner): Douze observations personnelles. Rev Neurol 1982; 138: 755-780.

17. Shoumaker RD, Bennett DR, Bray PF, et al. Clinical and EEG manifestations of an unusual aphasic syndrome in children. Neurology 1974; 24: 10-16.

18. McKinney W, McGreal DA. An aphasic syndrome in children. Can Med Assoc J 1974; 110: 637-639.

19. Rodriguez I, Niedermeyer E. The aphasia epilepsy syndrome in children: electroencephalographic aspects. Clin Electroencephalogr 1982; 13: 23-35.
20. Toso V, Moschini M, Gagnin G, et al. Aphasie acquise de l'enfant avec épilepsie. Trois observations et revue de la littérature. Rev Neurol (Paris) 1981; 137: 425-434.

21. Giovanardi Rossi P, Pazzaglia P, Frank G. Afasia acquisita con anomalie convulsive nell'etá evolutiva: estudio clinico, neuropsicologico ed elettroencefalografico di un caso. Riv Neurol 1976; 46: 130-162.

22. Hirsh E, Marescaux C, Maquet P, et al. Landau-Kleffner syndrome: A clinical and EEG study of five cases. Epilepsia 1990; 31: 756767.

23. Beaumanoir A, Ravnik I, Tassinari CA. Le syndrome de LandauKleffner. In: Roger J, Dravet C, Bureau M, Dreifuss F, Wolf P, eds. Les syndromes Epileptiques de L'Enfant et al L'Adolescent. London: John Libbey Eurotext Ltd, 1984; 185-195.

24. Otero E, Cordova S, Diaz F, et al. Acquired epileptic aphasia (Landau-Kleffner syndrome) due to neurocysticercosis. Epilepsia 1989; 30: 569-572.

25. Sawhney I, Suresh N, Dhand U, et al. Acquired aphasia with epilepsy-Landau-Kleffner syndrome. Epilepsia 1988; 29: 283287.

26. Billard C, Autret A, Laffont F, et al. Electrical status epilepticus during sleep in children: a reappraisal from eight new cases. $I n$ : Sterman M, Shouse M, Passouant P, eds. "Sleep and Epilepsy". London: Academic Press, 1982; 481-490.

27. Lerman-Sagie T, Statter M, Lerman P. Low erythrocyte zinc content in acquired aphasia with convulsive disorder (LandauKleffner syndrome). J Child Neurol 1987; 2: 28-30.

28. Pascual-Castroviejo I. Nicardipine in the treatment of acquired aphasia and epilepsy. Dev Med Child Neurol 1990; 32: 930 (letter).

29. Ferris EJ, Levine HL. Cerebral arteritis: classification. Radiology 1973; 109: 327-341.

30. Cupps TR, Moore PM, Fauci AS. Isolated angiitis of the central nervous system. Prospective diagnostic and therapeutic experience. Am J Med 1983; 74: 97-105.

31. Craven RS, French JK. Isolated angiitis of the central nervous system. Ann Neurol 1985; 18: 263-265.

32. Marescaux C, Hirsch E, Fink S, et al. Landau-Kleffner syndrome: A pharmacologic study of five cases. Epilepsia 1990; 31: 768777.

33. Ravnik I. A case of Landau-Kleffner syndrome: effect of intravenous diazepan. In: Roger J, Dravet C, Bureau M, Dreifuss FE, Wolf $P$, eds. Epileptic syndromes in infancy, childhood and adolescence. London: John Libbey, 1985; 192-193.

34. Lerman $P$, Lerman-Sagie T. Early steroid therapy in LandauKleffner syndrome. In: Manelis J, Bental E, Loeber JN, Dreifuss FE, eds. Advances in epileptology. XVIIth International Epilepsy Symposium. New York: Raven Press, 1989; 330-332.

35. Meyer FB, Anderson RE, Sundt TM Jr, et al. Selective central nervous system calcium channel blockers: a new class of anticonvulsant agents. Mayo Clin Proc 1986; 61: 239-247.

36. Morocutti C, Pierelli F, Sanarelli L, et al. Antiepileptic effects of a calcium antagonist (nimodipine) on cefazolin-induced epileptogenic foci in rabbits. Epilepsia 1986; 27: 498-503.

37. Binnie CD, de Beukelaar F, Meijer JWA, et al. Open dose-ranging trial of flunarizine as add-on therapy in epilepsy. Epilepsia 1985; 26: $424-428$

38. Overweg J, Binnie CD, Meijer JWA, et al. Double-blind placebocontrolled trial of flunarizine as add-on therapy in epilepsy. Epilepsia 1984; 25: 217-222.

39. Keene D, Whiting $S$, Humphreys $P$, et al. Flunarizine as a supplementary medication in refractory childhood epilepsy: A doubleblind crossover study. Can J Neurol Sci 1989; 16: 191-193.

40. Pascual-Castroviejo I. Tratamiento de la epilepsia rebelde con nicardipina. Drugs of Today 1988; 24 (Suppl 3): 191-201.

41. Maquet $P$, Hirsch E, Dive D, et al. Cerebral glucose utilization during sleep in Landau-Kleffner syndrome: A PET study. Epilepsia 1990; 31: 778-783. 